\title{
Abbreviations and Guide to Referencing
}

The following gives a key to Stiegler's principal texts, which have been referenced by way of abbreviations throughout.

In many cases, the abbreviations are followed by two sets of numbers, separated by a slash (/). The second set refers to the (French) original, and this is the case throughout the volume, where dual references have been given as a single bibliographical entry for both translation and original, rather than obscure the text with unnecessarily heavily parentheses. Where Stiegler references are followed by only a single set of page numbers, these refer to the translation - unless the text is only available in one language, be it English or French. Where deemed useful, they have been marked as either 'eng' or 'fr'.

In addition to those books already translated, a number of English versions of Stiegler are due to be published shortly. We have tried to anticipate their arrival by using the official translated titles in the text (for example, Symbolic Misery and What Makes Life Worth Living, both of which are forthcoming from Polity). We have also, where possible, given section numbers after the page reference, marked by $[\mathbb{S X X ]}$ in the text, so as to enable readers better to trace citations as and when the English becomes available. Unfortunately, the English-language publishers have not always respected the section numberings of Stiegler's originals, preferring to start again from $\mathbb{I}$ at the start of a new chapter, rather than retain the continuous section numbers of the French. This can at least be solved by counting - albeit not so easily in the case of $\mathrm{Ce}$ qui fait que la vie vaut la peine d'être vécue: De la pharmacologie (What makes Life Worth Living: On Pharmacology), where the French inexplicably skips from $\$ 23$ to $\mathbb{3} 0$ at the end of Chapter 3 ('On Pharmacology').

As is inevitably the case when a new thinker begins to appear 
in another language, there are multiple issues of translation that emerge only later, when translators' initial uncertainty gradually gives way to consensus over certain aspects of interpretation. This is exacerbated when the figure being translated is, both intellectually and stylistically, as formidably difficult as Stiegler, who tends to write by dictation, in tortuously long and syntactically complex sentences. His first wave of translators have been faced with a near-impossible task, and have unsurprisingly made mistakes. Rather than repeatedly drawing attention to these by highlighting the places in which citations have been modified, both the editors and contributors have simply retranslated where appropriate. The page numbers assigned to English translations are correct throughout - even if the words on the page are not quite the same.

$\mathrm{AH}$ 'Anamnesis and Hypomnesis: Plato as the first thinker of proletarianisation.' <http://www.arsindustrialis.org/ anamnesis-and-hypomnesis>

AO 'How I Became a Philosopher', in Acting Out, trans. David Barison, Daniel Ross and Patrick Crogan (Stanford: Stanford University Press, 2008); Passer à l'acte (Paris: Galilée, 2003).

CEI Constituer l'Europe, I: Dans un monde sans vergogne (Paris: Galilée, 2005).

CE2 Constituer l'Europe, 2: Le Motif européen (Paris: Galilée, 2005).

CPE For a New Critique of Political Economy, trans. George Collins and Daniel Ross (Cambridge: Polity, 2010); Pour une nouvelle critique de l'économie politique (Paris: Galilée, 2009).

DDI The Decadence of Industrial Democracies: Disbelief \& Discredit, vol I, trans. Daniel Ross and Suzanne Arnold (Cambridge: Polity, 20II); Mécréance et discrédit, vol I: La Décadence des democracies industrielles (Paris: Galilée, 2004).

DD2 Uncontrollable Societies of Disaffected Individuals: Disbelief \& Discredit, vol. 2, trans. Daniel Ross (Cambridge: Polity, 2012); Mécréance et discrédit, 2: Les Sociétés incontrôlables d'individus désaffectés (Paris: Galilée, 2006).

DD3 Mécréance et discrédit, vol III: L’Esprit perdu du capitalisme (Paris: Galilée, 2006). 
DP with Marc Crépon. De la démocratie participative: Fondements et limites (Paris: Mille et une nuits, 2006).

DSL 'Desire and Knowledge: The Dead Seize the Living', trans. George Collins and Daniel Ross (undated). <www.arsin dustrialis.org/desire-and-knowledge-dead-seize-living>

DT 'Deconstruction and Technology: Fidelity at the Limits of Deconstruction and the Prosthesis of Faith', trans. Richard Beardsworth, in Tom Cohen, ed., Jacques Derrida and the Humanities: A Critical Reader (Cambridge: Cambridge University Press, 200I).

EC États de choc: Bêtise et savoir au XXIe siècle (Paris: Mille et une nuits, 20I2).

EHP with Philippe Petit and Vincent Bontems. Économie de l'hypermatériel et psychopouvoir: Entretiens (Paris: Mille et une nuits, 2008).

ET with Jacques Derrida. Echographies of Television: Filmed Interviews, trans. Jennifer Bajorek (Cambridge: Polity Press, 2002); Échographies de la télévision: Entretiens filmés (Paris, Galilée, I996).

FI with Serge Tisseron. Faut-il interdire les écrans aux enfants? Entretiens réalisés par Thierry Steiner (Paris: Mordicus, 2009).

L 'To Love, To Love Me, To Love Us: From September I I to April 2I', in Acting Out (AO); Aimer, s'aimer, nous aimer: $D u$ I I septembre au 2 I avril (Paris: Galilée, 2003).

MAI 'Manifesto of Ars Industrialis', in The Re-enchantment of the World; 'Manifeste d'Ars Industrialis', in Réenchanterle monde (RW). <www.arsindustrialis.org/manifeste2005>

MAI2 'Manifesto of Ars Industrialis (20IO)'; 'Manifeste d'Ars Industrialis (20I0)'. <www.arsindustrialis.org/ manifeste-20IO>

MS 'The Magic Skin, or, The Franco-European Accident of Philosophy after Jacques Derrida', Qui Parle, vol. I 8/I (2009), pp. 97-Iıо; 'La Peau de chagrin ou L'accident franco-européen de la philosophie d'après Jacques Derrida', Rue Descartes, vol. 52 (2006), p. I03-I 2.

PA with Élie During. Philosopher par accident: Entretiens (Paris: Galilée, 2004).

PFM with Christian Fauré, et al. Pour en finir avec la 
mécroissance: Quelques réflexions d'Ars industrialis (Paris: Flammarion, 2009).

RW with Marc Crépon, George Collins and Catherine Perret. The Re-enchantment of the World: The Value of the Human Spirit versus Industrial Capitalism, trans. Trevor Arthur (London: Continuum, 2012); Réenchanter le monde: La Valeur esprit contre le populisme industriel (Paris: Flammarion, 2006).

SMI De la misère symbolique, I: L'Époque hyperindustrielle (Paris: Galilée, 2005).

SM2 De la misère symbolique, 2: La Catastrophe du sensible (Paris: Galilée, 2005).

TC Taking Care of Youth and the Generations, trans. Stephen Barker (Stanford: Stanford University Press, 20IO); Prendre soin, I: De la jeunesse et des générations (Paris: Flammarion, 2008).

TD La Télécratie contre la démocratie: Lettre ouverte aux représentants politiques (Paris: Flammarion, 2006).

TDI with Peter Hallward. 'Technics of Decision: An Interview', trans. Sean Gaston, in Angelaki, 8.2, pp. I 54-68.

TTI Technics and Time, I: The Fault of Epimetheus, trans. Richard Beardsworth and George Collins (Stanford: Stanford University Press, I998); La Technique et le temps, I: La Faute d'Épiméthée (Paris: Galilée, I994).

TT2 Technics and Time, 2: Disorientation, trans. Stephen Barker (Stanford: Stanford University Press, 2009); La Technique et le temps, vol. II: La Désorientation (Paris: Galilée, I996).

$\mathrm{TT}_{3}$ Technics \& Time, 3: Cinematic Time and the Question of Malaise, trans. Stephen Barker (Stanford: Stanford University Press, 20II); La Technique et le temps, vol. III: Le Temps du cinéma et la question du mal être (Paris: Galilée, 2003).

WML What Makes Life Worth Living: On Pharmacology, trans. Daniel Ross (Cambridge: Polity, 2013); Ce qui fait que la vie vaut la peine d'être vécue: De la pharmacologie (Paris: Flammarion, 20I0). 